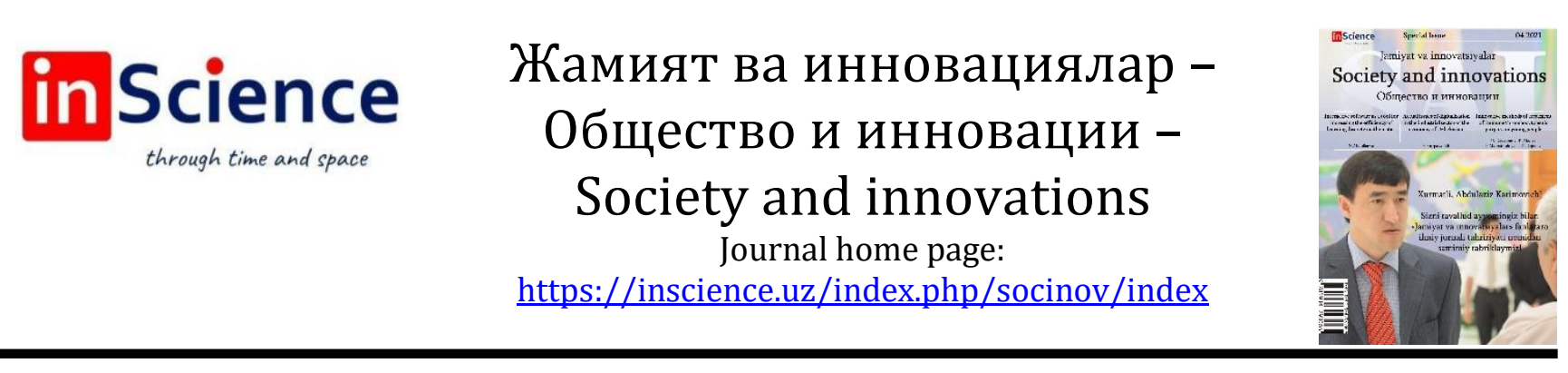

\title{
How to pronounce silent letters in English and French
}

\section{Dilfuza NOSIROVA ${ }^{\text {, Mehrigiyo 0'KTAMOVA }}{ }^{2}$}

\author{
Bukhara State university
}

\begin{tabular}{l} 
ARTICLE INFO \\
\hline Article history: \\
Received March 2021 \\
Received in revised form \\
20 March 2021 \\
Accepted 15 April 2021 \\
Available online \\
20 May 2021 \\
\hline
\end{tabular}

\section{Keywords:}

formation evolution, natural languages, further integration, modern educational, silent letter.

\begin{abstract}
According to the Law on Education, the National Training Program, new educational institutions have been built, and the existing ones have been reconstructed and repaired in accordance with modern standards. In the framework of the Law of the Republic of Uzbekistan "On Education" and the National Program of Personnel Training, a comprehensive system of teaching foreign languages, is the formation of a harmoniously developed, educated, modern-minded young generation, a system aimed at further integration of the republic into the world community has been created.

Silent letter is part of a word that written but not spoken. Silent letter can sometimes join with other letters to form part of a word. Silent letters exist in many English words and French words as well. Because of this, they often cause confusion and sometimes embarrassment when they are accidentally spoken. One of the reasons why silent letters are used in English, French and some other languages relates to following. During the formation evolution of English and French many foreign words were assimilated or absorbed in the language in Latin, Germanic, Greek words were readily added to early English and French as was the spelling. All natural languages change and because they change, they have histories. Every language changes in different ways, so their histories are unique and different. The history of a given language is the description of how it has changed over time.

2181-1415/C) 2021 in Science LLC.

This is an open access article under the Attribution 4.0 International (CC BY 4.0) license (https://creativecommons.org/licenses/by/4.0/deed.ru)
\end{abstract}

\footnotetext{
1 lecturer of the Department of Foreign language in Humanities, Bukhara State university. Bukhara, Uzbekistan.

${ }^{2}$ student of master's degree of Bukhara State university. Bukhara, Uzbekistan.
} 


\section{Ingliz va fransuz tillarida tovushsiz harflarning talaffuz qilinishi}

Kalit so'zlar:

shakllanish evolyutsiyasi,

tabiiy tillar,

keyingi integratsiya,

zamonaviy ta'lim,

ovozsiz xat.

\section{ANNOTATSIYA}

Ta'lim to'g'risidagi qonunga va Kadrlar tayyorlash milliy dasturiga binoan yangi ta'lim muassasalari barpo etildi va mavjudlari zamonaviy standartlar asosida rekonstruksiya qilindi va ta'mirlandi. O'zbekiston Respublikasining "Ta'lim to'g'risida" gi qonuni va Kadrlar tayyorlash milliy dasturi doirasida chet tillarini o'qitishning kompleks tizimi bu barkamol, bilimli, zamonaviy tafakkurli yosh avlodni shakllantirishga qaratilgan tizimdir.

Tovushsiz xat - bu yozilgan, ammo aytilmagan so'zning bir qismi. Tovushsiz harf ba'zan boshqa harflar bilan qo'shilib, so'zning bir qismini tashkil qilishi mumkin. Bu harflar ko'plab inglizcha so'zlarda va fransuzcha so'zlarda ham mavjud. Shu sababli, ular tasodifan gapirganda ko'pincha chalkashliklarni keltirib chiqaradilar va ba'zida xijolat bo'ladilar, ingliz, fransuz va boshqa ba'zi tillarda jim harflarning ishlatilishining sabablaridan biri quyidagilarga tegishli. Ingliz va frantsuz frantsuz evolyutsiyasi shakllanishida ko'plab xorijiy so'zlar lotin, german, singari singdirilgan yoki tilga singib ketgan, yunoncha so'zlar imlo kabi erta ingliz va frantsuz tillariga qo'shilgan. Barcha tabiiy tillar o'zgaradi va o'zgargani uchun ularning tarixlari bor. Har qanday til har xil shaklda o'zgaradi, shuning uchun ularning tarixi noyob va har xil. Muayyan tilning tarixi bu vaqt o'tishi bilan qanday o'zgarganligini tavsiflashdir.

\section{Произношение согласных букв на английском и французском языках}

Ключевые слова:

эволюция образования, естественные языки, дальнейшая интеграция, современное образование, безмолвное письмо.
АННОТАЦИЯ

Согласно Закону об образовании, Национальной программе обучения построены новые учебные заведения, а существующие реконструированы и отремонтированы в соответствии с современными стандартами. В рамках Закона Республики Узбекистан «Об образовании» и Национальной программы подготовки кадров комплексной системы обучения иностранным языкам происходит формирование гармонично развитого, образованного, современно мыслящего молодого поколения, система, направленная при дальнейшей интеграции республики в мировое сообщество.

Тихая буква - это часть слова, которое написано, но не произнесено. Тихая буква иногда может соединяться с другими буквами, образуя часть слова. Молчаливые буквы существуют во многих английских словах, а также во французских словах. Из-за этого они часто вызывают замешательство, а иногда и смущение, когда их случайно произносят. Одна из причин, почему молчаливые буквы 


\begin{abstract}
используются на английском, французском и некоторых других языках, связана со следующим. Во время формирования английского и французского языков многие иностранные слова были ассимилированы или поглощены языком в латинском, германском, греческие слова были легко добавлены к раннему английскому и французскому языкам, как и орфография. Все естественные языки меняются, и, поскольку они меняются, у них есть история. Каждый язык меняется по-разному, поэтому их истории уникальны и различны. История данного языка - это описание того, как он менялся с течением времени.
\end{abstract}

\title{
INTRODUCTION
}

The pronunciation of some of the words were simplified, while others were completely changed. This is why in modern languages which is being learned you will see many silent letters placed in common words. 53 Another reason for the use of silent letters is to avoid confusion between words with similar sounds and spelling. For example: plumplumb; hole-whole and others. In this regard, it is useful to distinguish the external history from the internal history. The former concerns the events that have happened to the speakers of Old English leading to changes in the language, for example, the Norman invasion that made French the official language of England for about three hundred years, which profoundly affected the English language, whereas the internal history refers to the changes that occur within the language itself and cannot be attributed directly to external forces. Since the Norman Conquest in 1066 and over the centuries, the Gallicisms or French expressions have been able to take root into the English lexicon thanks to the History that both languages have shared. It is worth noticing that the process of the linguistic transfer is somewhat complex. The conventionality of the lexicon is a process that gradually leads a lexical item to its introduction into a linguistic community. Through the contact with the speakers of the receiving language, the lexicon progressively takes the main features, such as pronunciation, of the said language. English has experienced many periods during which there have been different successive waves of loanwords from French and above all from Norman French.

\section{MATERIALS AND METHODS}

Also there are many words in English which use Silent letters, that more the same sound as other letters: threw-through, right-write. They make the same sound but as you can see the spelling is very different. Especially, " $h$ " is considered as the silent letter in French, for example, l'homme, habiter, l'habitude, héros, hiver and others. Some silent letters seem to have no logical purpose at all, for example: The "b" in "comb", "womb", "bomb" in English, "banale", "fatale", "natale" and others. There is only one letter changes between these words, yet they are pronounced differently. Other words containing Silent letters such as, campaign", "rhythm", "bureau" in English, but in French "fer-faire", "le-l'eau", "quand-can", "mais-mes, maire-mes" They are taken directly from other languages. The most common Silent languages are: B, H, K, T, U, W in English, and E, H, CH, $\mathrm{R}, \mathrm{T}, \mathrm{Q}$ etc. But the letter " $\mathrm{X}$ " is not a Silent letter in English. It starts a word by being pronounced as "z". Such as in "xylophone", and "xenophobia". This particular use stems from the language of the ancient Greeks. There is also the letter " $\mathrm{X}$ " which is silent letter in 
French such as "l' exercise", "l'exemple". The letter "s" is not pronounced as "z" when it comes between vowels,like that, la française, I'exercise, xenophobie, xylophone, xeresand the letter " $x$ " is the silent letter in these words: "doux", "douteoux", "here you can see more examples: French, like English, is not written phonetically. Vowels can be represented by several different letter combinations and many letters are actually not pronounced. The final consonant of many words is silent. Sometimes a final c, $\mathrm{f}, \mathrm{l}$ or rare pronounced though. Final c, f, l, r silent: blanc cléf outil parler franc cerf sourcil chercher tabac nerf gentil habiteres tomac persil fermer Final c, f, l, r pronounced: bouc œuf fil car lac sauf avril mer avec veuf civil pour donc actif col hiver Similar to English, final - e in most words is not pronounced. For feminine adjectives and nouns, this generally means that the final consonant of the masculine form will now be pronounced. Masculine and Feminine vert verte, grand grande, canadien canadienne, boulanger boulangère, chat chatte. A few silent letters were placed in French orthography for the prestige of being more similar to Latin. Other letters are now silent for other historical reasons (i.e. perhaps the pronunciation changed, but the spelling did not.) The following words all have silent letters: 54 Sept, rang, fils, trop, rompt, sang, pouls, camp, aspect, œil, saoul, chocolat, instinct, fauteuil, cul, credit, pied, ail, renault, riz, nid, drap, sirop, nez. A few plural nouns change their pronunciations to include silent letters, whereas these consonants are pronounced in the singular form: un œuf, des œufs, un bœuf, des bœufs, un os, des os. Here some more examples in English Silent B lamb [læm], lambs [læmz], jamb [jæm], climb [klaim], climbed [claimd], limb [lim], limbs [limz], bomb [bom], bombs [bomz], bomber ['bomər], comb [koum], combed [koumd]. Silent C Connecticut [kə'netikət], indict [in'dait], indictment [in'daitmənt], victuals ['vitlz], to victual ['vitl], Corpuscle ['ko:rpəsəl], ['ko:rpəsl] But: corpuscular [ko:r'pəskyələr], muscle ['məsəl], ['məsl], But: muscular ['məskyələr]. Silent D handkerchief ['hæykərchi:f], handsome ['hænsəm], Wednesday ['w enzdei]. Silent E late [leit], lately ['leitli], race [rei], racehorse ['reisho:rs], save [seiv], saved [seivd], life [laif], lifeless ['laiflis], drive [draiv], driveway ['draivwei], note [nout], notebook ['noutbuk] Silent GH high [hai], sigh [sai], thigh [0ai], weigh [wei], neighbor, neighbour ['neiborhud], dough

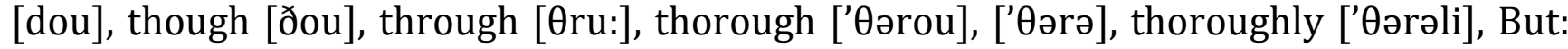
laughter ['læftər], ['la:ftər]. Silent H hour ['auər], honor, honour ['onər], honest ['onist], heir [eər], But: inherit [in'herit], inheritance [in'heritəns] But: who [hu:], whom [hu:m], whose [hu:z] Silent K know [nou], knit [nit], knee [ni:],kneel [ni:l], knife [naif], knives [naivz], knight [nait], knock [nok] Silent L calm [ka:m], balm [ba:m], palm [pa:m], salmon ['sæmən], almond ['a:mənd], ['æmənd]. Silent M mnemonic [ni'monik], [ni:'monik], mnemonics [ni'moniks], [ni:'moniks]. Silent N autumn ['o:təm] But: autumnal [o:'təmnəl], column ['koləm] But: columnar [kə'lemner]. Silent P pneumonia [nu'mouniə], [nyu:'mouniə], pneumatic [nu'mætik], [nyu:'mætik], psalm [sa:m], psalms [sa:mz], psalmist [sa:mist], psychology [sai'koləgi], psychologist [sai'koləgist], psyche ['saiki], psychic ['saikik]. But: corpse [ko:rps], corpus ['ko:rpəs]. SilentS aisle [ail], aisles [ailz], island ['ailənd], islands ['ailəndz], isle [ail], isles [ailz]. Silent T 55 listen ['lisən], glisten ['glisən], fasten ['fæsən], ['fa:sn], fastener ['fæsənər], ['fa:sənər],But: fast [fæst], hasten ['heisən], But: haste [heist]. Silent W who [hu:], whom [hu:m], whose [hu:z], whole [houl],wrack [ræk],wrangle ['ræygəl], ['ræygl], wrangler ['ræyglər],wrap [ræp] two [tu:], But: twice [twais], twenty ['twenti], twins [twinz]. English words that contain Silent letters: crumb, climb, thumb, lamb, doubt, limb, plumber, bomb, why, when, which, what, weather, ghost, white, while, honest, knot, knitting, know, knee, soften, listen, match, butcher, castle, 
guard, guess, guitar, guest, tongue, wreck, wrestling, whole, two, wrong. Instead of saying "when" a person might say "when. Instead of "what" we might say "what", just let the sound leave our lips naturally. In French there are also words that considered Silent letters like that le vent, le serpent, la serre, nous mangeons, langue, longue, la guitar, le match, trop, there is no doubt that Silent letters course confusion for everyone including native English students.

\section{RESULTS AND CONCLUSION}

We can compare letters with its placement within words. It is great way of familiarizing yourself with not only the spelling words. He was the foremost authority of his generation on medieval French language and lexicography. His greatest academic legacy was probably his editorship of the online Anglo-Norman Dictionary, which records the variety of French introduced to Great Britain by the Norman conquest of 1066 . There are big differences in pronunciation of 3 languages: there are special rules of pronunciation in French which Uzbek and English languages don to have. However, similarities can be noticed between these languages, as they belong to one family.

\section{REFERENCES:}

1. О.А. Колихалова, К.С. Махмурян, «Учитесь говорить по английски». Москва. 1998.

2. Marc Honcock, "English pronounciation in USE". Cambridge university press. 2014.

3. I.N. Popova, Kazakova. "Cours pratique de grammaire française"

4. Aliqulova D "Le manuel de française". 1999.

5. Bailey, Richard W. Images of English: A cultural History of the language. Cambridge University Press, 1992 Barber, Charles, Joan C. Beal and Phillip A. Shaw.

6. Baugh, Albert C,The English Language: Cambridge University Press, 2009 "The chronology of French Loan-words in English".

7. Baugh, Albert C. and Thomas Cable. Modern language Notes 50/2 (1935).

8. Rutledge, A history of the English Language. Sixth ed. London: 2013.

9. S. Zolotnitskaya. "Mon guide de français" Moskva,1993

10. D.M. Nosirova, The importance of using multimedia in a modern educational system. The teacher of Bukhara State university, 2020 Sologub, 200 тем французского языка. Moskva, 2007.

11. J. Yoqubov, "Guide de conversation" Toshkent, 2007.

12. S.S. Mirsagatova, "Le monde autour de nous" Toshkent, 2002. 